\title{
Mantle cell lymphoma
}

INSERM

\section{Source}

INSERM. (1999). Orphanet: an online rare disease and orphan drug data base. Mantle cell lymphoma. ORPHA:52416

Mantle cell lymphoma is a rare form of malignant non-Hodgkin lymphoma (see this term) affecting B lymphocytes in the lymph nodes in a region called the " mantle zone". 